\title{
Inovasi Teknologi Beras Sehat Analog Fungsional Untuk Kesejahteraan Masyarakat
}

\author{
Satrijo Saloko $^{1}$, Sri Widyastuti ${ }^{1}$, Rumiyati ${ }^{2}$, Rosmilawati ${ }^{3}$ dan Mita Eka Fitriani $^{1}$ \\ ${ }^{1}$ Fakultas Teknologi Pangan dan Agroindustri, Universitas Mataram, Mataram, Indonesia \\ ${ }^{2}$ Fakultas Farmasi, Universitas Gadjah Mada, Yogyakarta, Indonesia \\ ${ }^{3}$ Fakultas Pertanian, Universitas Mataram, Mataram, Indonesia
}

Kata Kunci:

Beras sehat

analog

fungsional,

diabetes,

obesitas,

teknologi

ekstrusi modern

\begin{abstract}
Abstrak: Ketergantungan masyarakat akan bahan makanan pokok berupa beras padi perlu dikurangi dengan cara diversifikasi pangan. Salah satu program yang tepat untuk diimplementasikan yaitu dengan memproduksi beras analog yang terbuat dari pangan lokal NTB dan memiliki sifat kimia, fisik dan mutu tanak mirip dengan beras padi. Dengan memanfaatkan program CARED bertemakan "Smallholder Livelihood Improvement through Small Scale Functional Analog Rice Food-Base Processing Enterprise: An Action-Research Approach to Smallholder Agribusiness and Food Processing Industrial Development in East Lombok - West Nusa Tenggara Province"yang melibatkan kerjasama antara Universitas Mataram, (Fakultas Teknologi Pangan dan Agroindustri dengan Fakultas Pertanian)- New Zealand (Massey University)- Universitas Gadjah Mada (Fakultas Farmasi, Fakultas Biologi dan Fakultas Teknologi Pertanian), tim peneliti berhasil mengembangkan Beras Sehat Analog Fungsional dengan menggunakan teknologi ekstrusi modern. Hasil Analisa laboratorium menunjukkan formula beras sehat analog fungsional menghasilkan beras analog yang memiliki Indeks Glikemik (IG) sebesar 64,01, lebih rendah dibandingkan IG beras biasa sebesar 95.96. Sehingga, beras sehat analog fungsional dapat dikonsumsi oleh penderita diabetes dan obesitas. Selain itu, berdasarkan hasil uji organoleptik dan hasil survey di lapangan, tingkat kesukaan terhadap beras sehat berada pada tingkat baik yang membuat permintaan beras sehat analog fungsional meningkat setiap bulan. Hal ini membuktikan bahwa beras sehat analog fungsional dapat menjadi solusi alternatif dalam diversifikasi pangan dan dapat mengatasi permasalahan kesehatan masyarakat karena mudah diproduksi dan kandungan gizi yang bisa disesuaikan sesuai dengan kebutuhan masyarakat.
\end{abstract}

Korespondensi: s_saloko@unram.ac.id

\section{PENDAHULUAN}

Masyarakat Indonesia saat ini dikenal memiliki makanan pokok berupa beras padi. Padahal, beberapa decade yang lalu, masyarakat Indonesia mengkonsumsi segala pangan yang memiliki sumber karbohidrat yang tinggi, seperti singkong, ubi, jagung, talas dan pangan lainnya. Namun, saat ini, ketergantungan akan beras padi semakin memprihatinkan. Dampak ketergantungan yang semakin tinggi mengakibatkan permasalahan lingkungan dan kesehatan. Beberapa akibat dari ketergantungan ini antara lain jumlah penderita diabetes dan obesitas semakin tinggi serta permintaan yang tidak selaras dengan ketersediaan lahan untuk menanam padi. Berdasarkan WHO (2018), jumlah penderita diabetes secara global mengalami kenaikan dari 4,7\% pada tahun 1980 menjadi 8,5\% pada tahun 2014 dan kenaikan jumlah penderita diabetes lebih sering terjadi pada negara berkembang, seperti Indonesia. Pada tahun 2000, Indonesia menduduki peringkat ke-4 di dunia dengan jumlah penderita diabetes sebanyak 8,4 juta dan diprediksi angka ini akan naik ke 21,3 juta pada tahun 2030 
(Depkes, 2018). Diabetes dikenal juga sebagai penyakit penyebab kematian ke tujuh pada tahun 2016.

Alasan kedua akan pentingnya diversifikasi pangan yaitu keterbatasan lahan untuk menanam padi yang mengakibatkan jumlah produksi beras semakin menurun sedangkan permintaan semakin meninggi. BPS menyebutkan permintaan beras berada pada angka 30 juta ton dengan pertumbuhan sebesar $1,71 \%$ per tahun. Sedangkan luas keseluruhan sawah pada saat ini mengalami penurunan karena adanya pembangunan infrastruktur yang bukan hanya terjadi di wilayah perkotaan namun juga di wilayah perdesaan. Terhitung dari tahun 1979-2000, jumlah konversi lahan sawah sebesar $475.042 \mathrm{Ha}$.

Dengan mempertimbangkan permasalahan diatas yang semakin menghiraukan, maka, diperlukan adanya diversifikasi pangan yang memanfaatkan kekayaan pangan lokal, contohnya kacang gude, singkong, jagung dan rumput laut yang aman untuk dikonsumsi oleh seluruh lapisan masyarakat. Di NTB, singkong atau ubi kayu, jagung, kacang gude dan rumput laut dapat ditemukan dengan mudah dan memiliki potensi yang besar untuk dikembangkan sebagai pangan sumber karbohidrat alternatif pengganti beras, Selain itu, pangan lokal tersebut dapat ditanam di lahan kering. Sehingga, hal ini dapat mewujudkan ketersediaan pangan yang aman, bergizi, berkelanjutan, bermutu dan dapat dijangkau oleh seluruh lapisan masyarakat (Seismono, 2008).

Tepatnya pada tahun 2016, dua universitas ternama di Indonesia terdiri dari Universitas Mataram dan Universitas Gajah Mada, mengadakan kerjasama dengan Massey University yang berasal dari New Zealand melalui program CARED yang mengusung tema "Smallholder Livelihood Improvement through Small Scale Functional Analog Rice FoodBase Processing Enterprise: An Action-Research Approach to Smallholder Agribusiness and Food Processing Industrial Development in East Lombok - West Nusa Tenggara Province" dan berhasil menciptakan beras sehat analog fungsional untuk mengatasi berbagai permasalahan yang timbul akibat ketergantungan akan bahan pangan pokok berupa beras padi.

\section{METODE KEGIATAN}

Metode yang digunakan untuk membuat beras sehat analog yaitu teknologi ekstrusi modern yang memanfaatkan mesin ekstruder ulir ganda. Hasil cetakan mesin ekstruder jenis ulir ganda menghasilkan bulir yang mirip dengan bulir beras pada umumnya. Jenis ekstrusi yang digunakan yaitu Hot extrusion dimana komposisi beras sehat analog fungsional yang terdiri dari singkong, jagung, kacang gude dan rumput laut yang sudah dijadikan tepung dimasukkan kedalam ekstruder ulir ganda yang bersuhu $70-100^{\circ} \mathrm{C}$ (Alavi, 2008). 


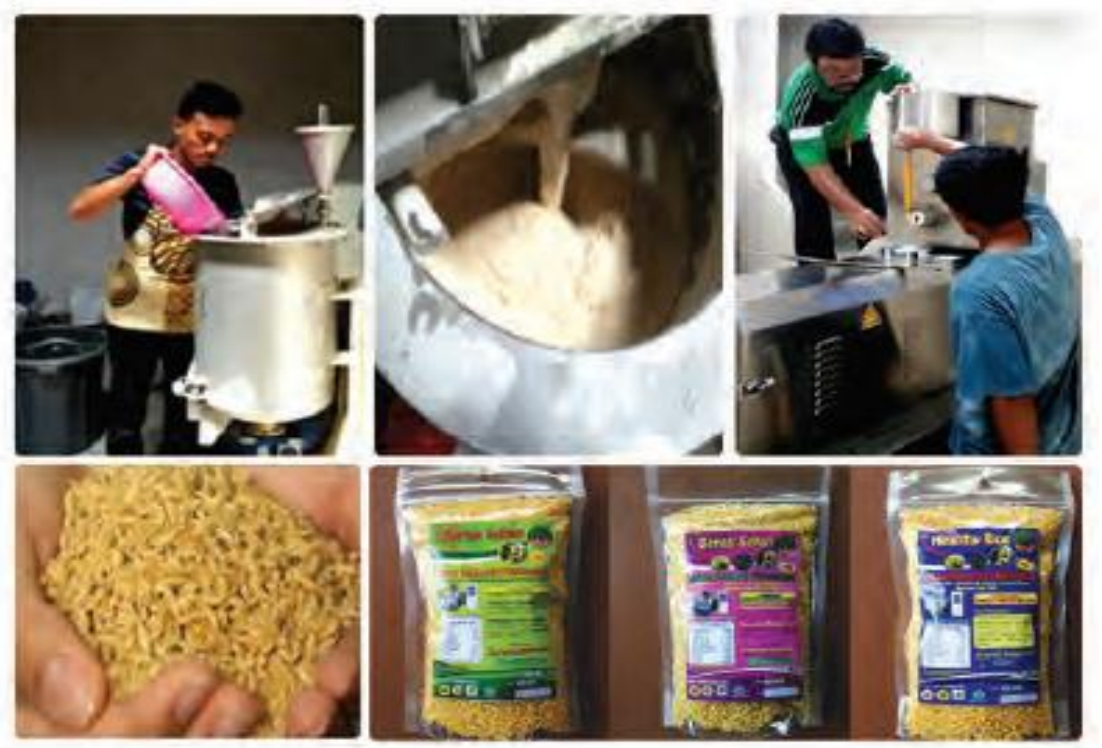

Gambar 1: Proses produksi beras sehat analog fungsional di UD Kaya Rasa

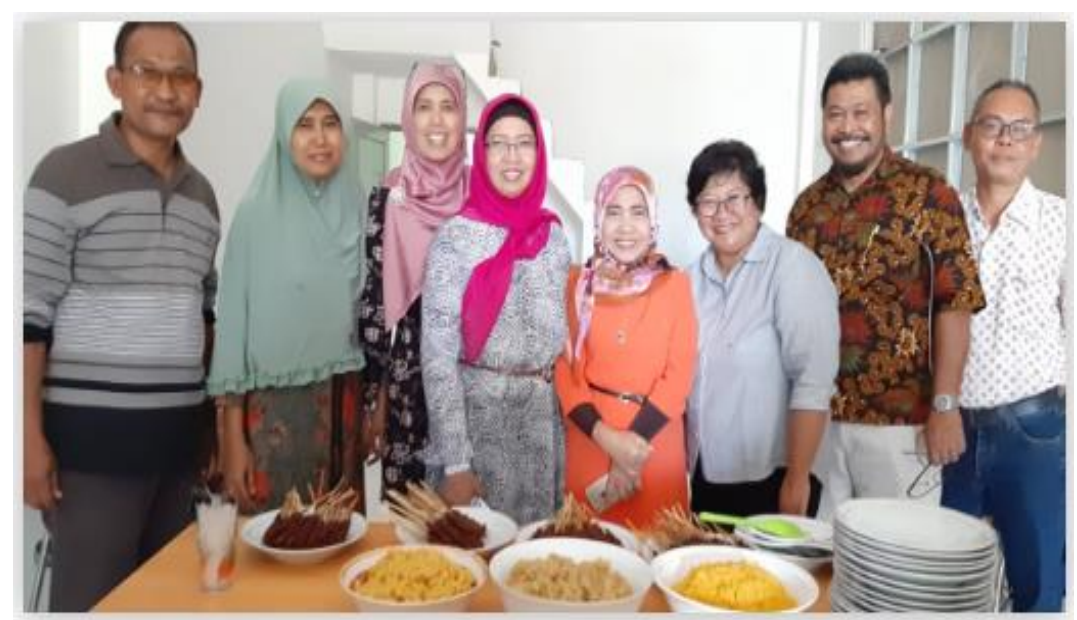

Gambar 2: Tim operasional beras sehat analog fungsional

\section{HASIL DAN PEMBAHASAN}

a. Hasil Analisa Laboratorium

Beras sehat analog fungsional meiliki tiga variasi. Variasi A terbuat dari singkong, jagung dan minyak sayur. Variasi B dibuat dari komposisi singkong, jagung, kacang gude (lebui) dan rumput laut, sedangkan variasi C terbuat dari singkong, jagung, kacang gude, rumput laut dan minyak sayur. Hasil analisa laboratorium menunjukkan nilai glikemik indeks beras sehat analog berada pada angka yang lebih rendah dibandingkan nilai glikemik indeks beras padi. Berikut komposisi gizi beras sehat analog fungsional dan beras padi. 
Tabel 1: Perbandingan komposisi gizi beras sehat analog fungsional dengan beras padi

\begin{tabular}{l|c|c|c}
\hline \multirow{2}{*}{ Parameter } & \multirow{2}{*}{ Beras Padi } & \multicolumn{2}{c}{ Beras Sehat Analog Fungsional } \\
\cline { 3 - 4 } & & UGM & UNRAM \\
\hline Karbohidrat (\%) & 28 & 74,39 & 88,20 \\
\hline Protein (\%) & 7 & 6,73 & 5,42 \\
\hline Lemak (\%) & 1 & 0,21 & 0,16 \\
\hline Air (\%) & 10,8 & 7,30 & 6,22 \\
\hline Abu (\%) & 0,5 & 1,20 & 0,93 \\
\hline Serat Kasar (\%) & 0,4 & 3,74 & 3,74 \\
\hline Kadar Antosianin (ppm) & - & 13,77 & 6,58 \\
\hline Indeks Glikemik & 94 & 64,01 & 64,01 \\
\hline Fe (ppm) & 0,9 & 37,11 & 39,52 \\
\hline Zn (ppm) & 26,35 & 12,39 & 11,99 \\
\hline Ca (ppm) & 15 & 1277,63 & 1839,64 \\
\hline
\end{tabular}

Beras sehat analog fungsional memiliki beberapa keunggulan dibandingkan dengan beras padi, anatara lain:

1. Beras sehat analog fungsional memiliki gizi yang lebih lengkap dan menyehatkan dibandingkan dengan beras padi.

2. Kadar karbohidrat yang tinggi pada beras sehat analog fungsional yang diproduksi oleh UNRAM menghasilkan indeks glikemik yang sama dengan beras sehat analog fungsional yang diproduksi oleh UGM. Hal ini dipicu oleh formulasi yang hampir mirip antara satu sama lain.

3. Tekstur yang dihasilkan oleh beras sehat analog fungsional lebih pulen ketika disantap hangat dan memiliki aroma perpaduan singkong, jagung, kacang gude dan rumput laut yang khas. Selain itu, warna beras yang dihasilkan oleh beras sehat analog fungsional lebih menarik dipandang mata, walaupun terlihat lebih gelap karena adanya kandungan kacang gude.

4. Kadar protein beras sehat analog (6\%) lebih rendah dari kadar protein beras padi $(9 \%)$ (Hong, 1971). Kadar protein pada beras sehat analog fungsional dapat mempengaruhi nilai indeks glikemik. Semakin rendah kadar protein pada beras sehat analog fungsional, maka nilai indeks glikemik cenderung menurun (Rimbawan dan Siagian, 2004).

5. Kadar air beras sehat analog yang lebih rendah (7\%) dibandingkan kadar air beras padi $(10 \%)$, menunjukkan beras sehat analog fungsional dapat disimpan dalam jangke waktu yang lebih lama karena pada kadar air 7\%, pertumbuhan mikroba pada beras sehat analog fungsional berjalan lebih lambat dibandingkan dengan beras padi. Semakin tinggi kadar air pada bahan pangan, maka semakin tinggi kemungkinan mikroba tumbuh dengan cepat pada bahan pangan tersebut. Kadar air beras sehat analog fungsional yang rendah kemungkinan disebabkan oleh penggunakan temperatur dan tekanan yang tinggi ketika bahan komposisi beras sehat analog fungsional dimasukkan kedalam mesin ekstruder.

6. Kadar abu beras sehat analog fungsional $(1,2 \%)$ lebih tinggi dibandingkan dengan kadar abu beras padi $(0,5 \%)$. Hal ini menunjukkan kandungan mineral pada beras sehat analog fungsional lebih tinggi dibandingkan dengan beras padi (Winarno, 
1997). Mineral yang tinggi dapat terlihat dari kadar zat besi (Fe) dan kalsium (Ca) pada beras sehat analog fungsional begitu tinggi, yaitu sebesar 37,11 ppmdan 1277,63 ppm berturut turut.

7. Kadar lemak pada beras sehat analog fungsional berada pada angka $0,21 \%$, lebih rendah dibandingkan dengan beras padi yaitu sekitar $0,6 \%$. Artinya, dengan kadar lemak yang lebih rendah, beras sehat analog fungsional dapat dikonsumsi oleh penderita obesitas yang membutuhkan makanan rendah lemak.

8. Nilai indeks glikemik pada beras sehat analog fungsional (64.01) lebih rendah dibandingkan dengan nilai indeks glikemik beras padi (95.96). Hal ini dapat mempengaruhi penyerapan gula di dalam tubuh. Ketika nilai indeks glikemik rendah, gula darah dan berat badan dapat dikontrol.

9. Kadar serat beras sehat analog fungsional sejumlah 3,74\%, lebih tinggi dibandingkan jumlah serat pada beras padi sejumlah $0,5 \%$. Tingginya serat pada beras sehat analog fungsional sangat berfungsi untuk menjaga kesehatan pencernaan. Dalam penelitian Anderson (1994), pangan yang mengandung serat tinggi dapat menurukan kolesterol, menurunkan tekanan darah, dapat mengontrol berat tubuh, merendahkan potensi berbagai jenis kanker dan memperbaiki kesehatan pencernaan.

10. Cara memasak beras sehat analog fungsional lebih praktis dibandingkan dengan beras padi, sehingga waktu yang dibutukan untuk memasak beras sehat analog fungsional lebih singkat.

11. Beras sehat analog fungsional hanya membutuhkan air yang sedikit untuk mencuci beras, yaitu hanya sekali cuci, sedangkan beras padi biasanya dicuci tiga kali sebelum dimasak, sehingga penggunaan beras sehat analog fungsional dapat mendukung pemerintah dalam penghematan penggunaan air.

12. Kandungan gizi pada beras sehat analog fungsional dapat dimodifikasi sesuai dengan kebutuhan masyarakat. Contohnya, beras sehat analog fungsional yang diformulasikan untuk penderita diabetes dan obesitas.

13. Beras sehat analog fungsional dapat diproduksi secara massal karena memanfaatkan kearifan pangan lokal yang tersedia cukup melimpah di Indonesia. Di Nusa Tenggara Barat, beras sehat analog fungsioanl bukan hanya bisa dibuat dari singkong, jagung, kacang gude dan rumput laut, namun juga bisa berasal dari berbagai jenis umbi-umbian lainnya.

14. Dengan mengkonsumsi beras sehat analog fungsional, jumlah impor beras dapat ditekan sehingga pangan lokal asli Indonesia dapat berjaya di tanah air nusantara.

b. Hasil organoleptik

Hasil organoleptik yang memanfaatkan indra manusia dalam mengukur daya penerimaan terhadap produk beras sehat analogfungsional menunjukkan tingkat kesukaan panelis terhadap beras sehat analog fungsional memberikan hasil positif. Artinya, panelis dapat menerima produk beras sehat analog fungsional dengan baik. 
c. Hasil survey di lapangan

Survey dilaksanakan pada bulan Juli-Agustus 2019 di wilayah NTB, meliputi Kota Mataram, Lombok Barat, Lombok Timur, Lombok Tengah, Lombok Utara, Sumbawa, Bima dan Dompu secara online dan offline. Offline survey dimana masing masing surveyor mewawancarai 20 responden yang mengidap penyakit diabetes, sedangkan online survey dilaksanakan dengan mengirimkan kuisioner secara online ke berbagai lapisan masyarakat untuk mengetahui tanggapan masyarakat terhadap beras sehat analog. Segala informasi yang berkaitan dengan beras sehat analog diinformasikan kepada masyarakat, seperti cara menyajikan beras sehat analog fungsioanl menggunakan rice cooker atau dandang, manfaat beras sehat analog fungsional terhadap kesehatan, pentingnya diversifikasi pangan demi keberlanjutan pangan lokal, dan informasi tentang ancaman diabetes yang disebabkan oleh terlalu tinggi kadar gula yang dihasilkan oleh beras padi.

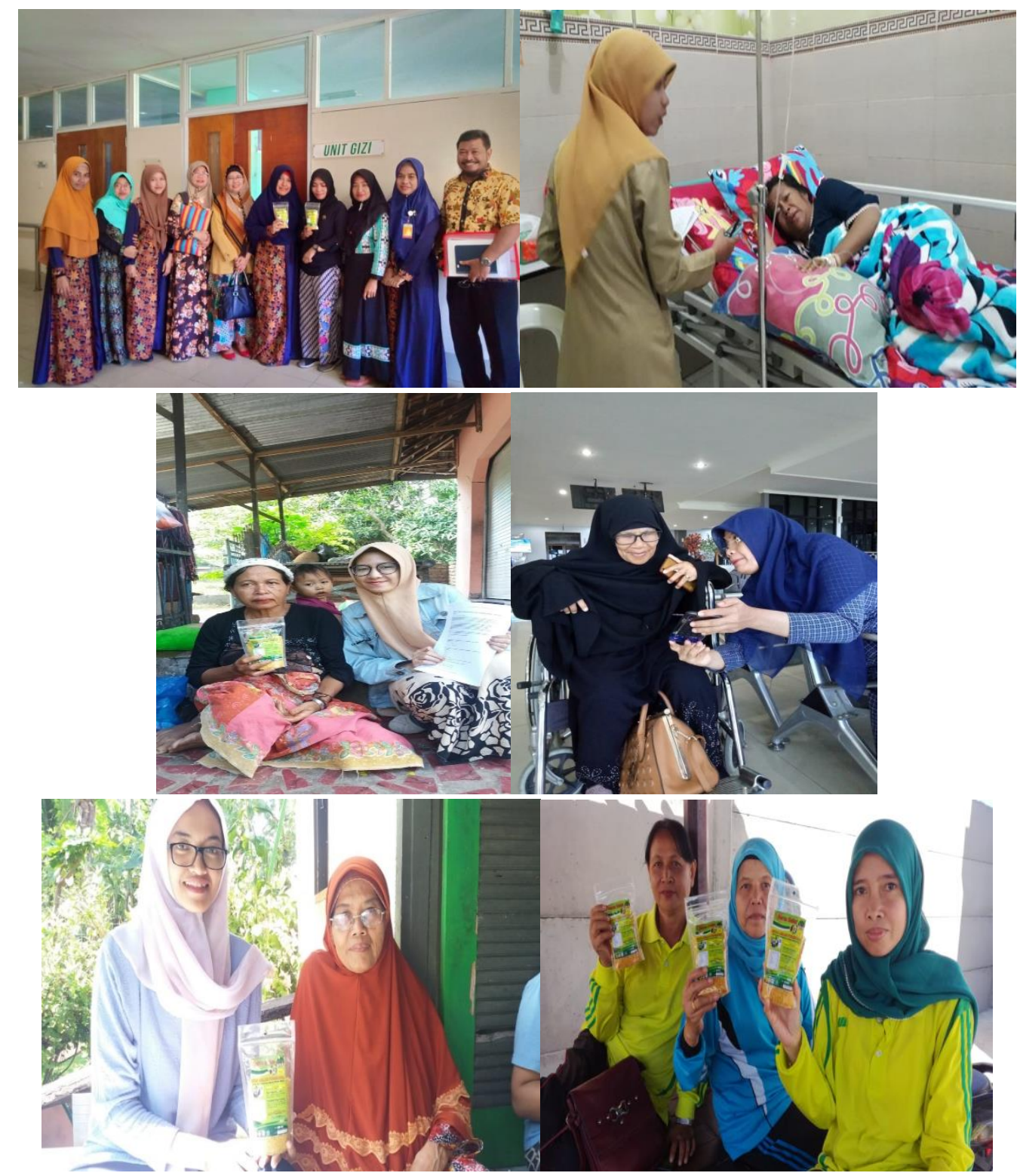

Gambar 3: Survey lapangan beras sehat analog fungsional 
Hasil survey menunjukkan adanya antusias yang tinggi terhadap produk beras sehat analog fungsional karena beras sehat analog fungsional bukan hanya menawarkan pemenuhan pangan sehat namun juga harga yang ditawarkan lebih terjangkau dibandingkan dengan beras sejenis yang ada di market. Terbukti, pemasaran beras analog berjalan lancar dan permintaan beras sehat analog semakin meningkat setiap bulan.

d. Kegiatan sosialisasi dan promosi yang sudah dilaksanakan

Kegiatan sosialisasai dan promosi yang sudah dilaksanakan oleh tim riset diantaranya:

1. Pembagian sample produk yang berukuran 250 gr sebanyak 500 bungkus kepada masyarakat yang tersebar di kota mataram, kabupaten Lombok barat, kabupaten Lombok timur, kabupaten Lombok tengah, kabupaten Lombok utara, kabupaten Sumbawa, Dompu dan Bima. Masyarakat yang menerima beras sehat analog fungsional adalah penderita diabetes yang sedang rawat inap ataupun rawat jalan di beberapa rumah sakit yang ada pada daerah yang telah disebutkan. Pembagian sample produk beras sehat analog fungsional juga melibatkan para praktisi kesehatan, seperti dokter, perawat, pegawai di Dinas Kesehatan untuk membantu mensosialisasikan produk beras sehat analog fungsional.

2. Pengadaan lomba cipta menu beras sehat analog fungsional pada beberapa event.

3. Pengadaan workshop, pertemuan formal dan non-formal, salah satunya yaitu FGD Maket Research Produk "Beras Sehat Analog Fungsional” Yogyakarta.

4. Mengikuti berbagai acara untuk memperkenalkan beras sehat analog fungsional, contohnya NTB EXPO, mengikuti acara sesi foto beras sehat analog yang diselenggarakan oleh PLUT NTB dan komunitas Fotografer NTB.

5. Demo cara memasak dan menyajikan beras sehat analog fungsional di berbagai event dan media informasi.

6. Melakukan sosialisasi di berbagai media sosial. Informasi penting tentang beras sehat analog fungsional dapat ditemukan di website resmi beras sehat analog fungsional di alamat https://healthyfoods.id/. Bukan hanya menyajikan informasi seputar teknologi beras sehat analog fungsional, melalui website customer bisa memesan beras sehat analog fungsional secara langsung yang terkoneksi dengan nomer whatsapp salah satu tim beras sehat analog fungsional. Untuk mengetahui event event yang pernah dihadiri oleh beras sehat analog fungsional, customer bisa mengunjungi Instagram beras sehat analog fungsional dengan alamat https://www.instagram.com/berassehatanalog/. Selain itu, untuk mempererat silaturrahmi antara penikmat beras sehat analog fungsional, terdapat grup whatsapp Healthy Lifestyle, dimana para peserta grup dalam berbagi pengalaman ketika memasak dan mengkonsumsi beras sehat analog fungsional. Bagi pengguna media sosial facebook, informasi terkait beras sehat analog fungsional juga bisa didapatkan melalui fanpage beras sehat analog fungsioanl di alamat https://www.facebook.com/berassehatanalog. Bagi pengguna youtube, informasi terkait beras sehat analog fungsional, seperti cara memasak dan menyajikan beras sehat analog fungsional dapat mengunjungi Chanel Youtube Rosmila AR dan 
mengakses video beras sehat analog fungsional di alamat https://youtu.be/zlLlBM0vAXA.

7. Melakukan penjualan secara online dan offline. Penjualan secara online dilakukan melalui berbagai marketplace, seperti tokopedia dengan alamat https://tokopedia.link/UD5M300fNY, bukalapak dengan alamat https://www.bukalapak.com/p/food/bahan-mentah/21sn635-jual-beras-sehat-analogfungsional-250g-untuk-penderita-diabetes, shopee dengan alamat https://shopee.co.id/product/18363516/2589488725?v=eed\&smtt=0.0.3 dan grup facebook salah satunya di grup jual beli online daerah mataram dan sekitarnya. Penjualan secara offline dilakukan dengan melibatkan para reseller yang tersebar di berbagai daerah dan rumah sakit di Nusa Tenggara Barat dan Jawa Tengah.

\section{KESIMPULAN DAN SARAN}

Dengan adanya inovasi teknologi beras sehat yang menggunakan teknologi ekstrusi terkini, masyarakat menyadari bahwa bahan pangan lokal memiliki potensi sebagai bahan diversifikasi pangan dan beras sehat analog fungsional hadir untuk mensejahterakan masyarakat dalam aspek kesehatan demi menjungjung tinggi "healthy lifestyle", efektifitas bahan pangan lokal, dan berfungsi dalam aspek ekonomi demi mensejahterakan petani lokal.

Berdasarkan hasil studi yang telah dilakukan, diperlukan adanya sinergi antara seluruh pihak, baik masyarakat, peneliti dan pemerintah untuk mewujudkan diversifikasi pangan secara maksimal, sehingga pangan lokal yang merupakan komposisi utama beras sehat analaog fungsional memiliki daya saing tinggi dan daya penerimaan yang tinggi dibandingkan dengan beras padi. Selain itu, diperlukan adanya subsidi bahan utama beras sehat analog fungsional sehingga masyarakat level menengah kebawah dapat mengkonsumsi beras sehat analog fungsional secara rutin yang nantinya diharapkan akan menurunkan jumlah penderita diabetes di Indonesia.

\section{Ucapan Terima Kasih}

Penulis mengucapkan terima kasih kepada Program CaRED yang diinisiasi Pemerintah New Zealand melalui Universitas Gadjah Mada yang telah melakukan kolaborasi kegiatan dengan Universitas Mataram dengan Dinas Ketahanan Pangan Provinsi Nusa Tenggara Barat untuk pendanaan dan fasilitas selama kegiatan ini berlangsung. Seluruh tim yang telah terlibat dalam penelitian dan sosialisasi beras sehat analog fungsional, serta jajaran di Pemerintah Provinsi NTB, pegawai di rumah sakit se-Kabupaten/Kota Provinsi NTB, Reseller dan lapisan masyarakat yang telah membantu mensosialisasikan dan mempromosikan beras sehat analog fungsional.

\section{DAFTAR PUSTAKA}

Alavi, S., Bugusu, B. and Cramer, G. 2008. Rice Fortification in Developing Countries: a Critical Review of The Technical dan Economic 
Anderson, J. W., Smith, B. M., \& Gustafson, N. J. (1994). Health benefits and practical aspects of high-fiber diets. The American journal of clinical nutrition, 59(5), $1242 \mathrm{~S}-1247 \mathrm{~S}$.

BPS. 1991-2001. Neraca Bahan Makanan Indonesia. Badan Pusat Statistik Jakarta.

Depkes (2018). Info Datin Hari Diabetes Sedunia. Diakses pada tanggal 10 September 2019. http://www.depkes.go.id/resources/download/pusdatin/infodatin/haridiabetes-sedunia-2018.pdf

Hong, L. G., Nio, O. K., \& Prawiranegara, D. D. (1971). Nilai Gizi Beras Lima Varitas Padi Unggul. Penelitian Gizi dan Makanan (The Journal of Nutrition and Food Research).

Rimbawan A and Siagian S 2004 Food Glycemic Index 'Easy Way to Choose Healthy Food' (in Bahasa Indonesia) (Jakarta: Penebar Swadaya)

Rohaeni, W. R., Supriadi, E., Susanto, U., \& Rosahdi, T. D. (2016). Kandungan Fe dan Zn pada beras pecah kulit dan beras sosoh dari galur-galur padi toleran wereng batang cokelat. Jurnal Ilmu Pertanian Indonesia, 21(3), 172-176.

Seismono (2008). Teknologi Pengolahan dan Pemanfaatan Pangan Lokal Berbasis UmbiUmbian. Edisi No.52/XVII/Oktober-Desember/2008

WHO (2018). Diabetes. Diakses pada tanggal 10 September 2019 (https://www.who.int/news-room/fact-sheets/detail/diabetes)

Winarno, F.G. (1997) Food Chemistry and Nutrition. Gramedia, Jakarta 